\title{
Coproverdine, a Novel, Cytotoxic Marine Alkaloid from a New Zealand Ascidian
}

\author{
Sylvia Urban, J ohn W. Blunt, and Murray H. G. Munro* \\ Department of Chemistry, University of Canterbury, Private Bag 4800, Christchurch, New Zealand
}

Received November 21, 2001

The crude extract of a New Zeal and ascidian displayed antitumor activity. Bioassay-directed fractionation yielded a novel alkaloid, coproverdine (1). The structure of $\mathbf{1}$ was assigned on the basis of detailed spectroscopic analysis. Coproverdine (1) was responsible for the antitumor activity of the crude extract.

In our continuing search for new anticancer lead compounds from marine organisms, an unidentified New Zeal and ascidian was studied. This resulted in the isol ation of the novel alkaloid coproverdine (1), possessing a carbazole ring. Coproverdine (1) was obtained from a rare, poorly identified ascidian collected at a depth of 20-25 m from a rock wall in an exposed but shaded area at Irishman's Garden, Three Kings, $55 \mathrm{~km}$ offshore from the northern tip of the North I sland of New Zealand. (The taxonomy of this specimen remains unknown. The specimen was initially examined by Mr. M. Page, NIWA, New Zealand, and later by Dr. P. Kott (Mather), Queensland Museum, Australia. The name given to the alkaloid was derived from the descriptor attached to the voucher specimen ("green sheep-shit-like in appearance"), hence coproverdine (copro Greek dung, ovis Latin sheep, verde Latin green).) A voucher specimen is stored in the museum at NIWA, Wellington, New Zealand (NIWA code MNP670). Although the specimen was poorly preserved, it was considered to possibly be a polycitorid. The crude extract of this specimen displayed cytotoxic activity against the P388 (murine leukaemia) cell line and also against the slow growing BSC-1 (African green monkey kidney) cell line. The total, size-limited frozen sample (34 g) was extracted with $\mathrm{MeOH}$ / DCM. The extract was initially separated by RP vacuum liquid chromatography, followed by gel permeation chromatography (LH-20). Final purification was achieved using reversed-phase HPLC to yield the major metabolite coproverdine (1) (5 mg, $0.01 \%)$ as a yellow oil, $[\alpha]_{D}-8^{\circ}$. The molecular formula was established by HRFABMS and HREIMS as $\mathrm{C}_{15} \mathrm{H}_{11} \mathrm{NO}_{6}$, thus requiring $11 \mathrm{DBE}$. The ${ }^{13} \mathrm{C}$ NMR spectrum of 1 contained 15 resolved signals (one methyl, six methines, and eight quaternary carbons as supported by a gHSQC NMR experiment). The IR spectrum of $\mathbf{1}$ had absorptions at $3690 \mathrm{~cm}^{-1}$ (sharp) and $3500 \mathrm{~cm}^{-1}$ (broad), suggestive of both hydrogen-bonded and free hydroxyl groups. In the ${ }^{1 \mathrm{H}}$ NMR spectrum one of the exchangeable protons [ $\delta 8.50$ (bs)] was observed while the other was not, presumably due to rapid exchange.

The UV absorption at $382 \mathrm{~nm}$ was suggestive of a conjugated indole moiety, ${ }^{1}$ while an IR absorption at 1665 $\mathrm{cm}^{-1}$ together with the NMR data ( $\delta 10.13$ (s); 192.7) indicated the presence of a formyl group. Also present were a methyl ester grouping ( $\delta 4.06$ (s); 53.4 and 168.2) and a ketone ( $\delta$ 186.4).

Two key structural fragments were identified from the ${ }^{1} \mathrm{H}$ and COSY NMR data. First, a 1,2,3-trisubstituted aromatic ring [ $\delta 7.84(\mathrm{dd}, \mathrm{J}=1.5,8.0 \mathrm{~Hz}), 7.28(\mathrm{dd}, \mathrm{J}=$ 8.0, 8.0 Hz), and 7.39 (dd, J = 1.5, 8.0 Hz)] and, second, a

* Corresponding author. Tel: +64 3364 2434. Fax: +64 33642110 E-mail: m.munro@chem.canterbury.ac.nz.
Table 1. NMR Data for Coproverdine (1)

\begin{tabular}{|c|c|c|c|c|}
\hline no. & ${ }^{13} \mathrm{C}^{\mathrm{b}}$ & ${ }^{1} \mathrm{H} \delta[\mathrm{m}, \mathrm{J}(\mathrm{Hz})]^{\mathrm{c}}$ & gCOSY & $\mathrm{gHMBC}^{\mathrm{d}}$ \\
\hline 1 & 90.5 & & & \\
\hline 2 & 143.6 & $7.01(\mathrm{~d}, \mathrm{~J}=10.2)$ & $\mathrm{H} 3$ & $\mathrm{C} 1, \mathrm{C} 4, \mathrm{C} 9 \mathrm{a}, \mathrm{C} 10^{\circ}$ \\
\hline 3 & 128.5 & $6.25(\mathrm{~d}, \mathrm{~J}=10.2)$ & $\mathrm{H} 2$ & $\begin{array}{l}\mathrm{C} 1, \mathrm{C} 2, \mathrm{C} 4, \mathrm{C} 4 \mathrm{a} \\
\mathrm{C} 10^{\mathrm{e}}\end{array}$ \\
\hline 4 & 186.6 & & & \\
\hline $4 a$ & 105.7 & & & \\
\hline $4 b$ & 127.7 & & & \\
\hline 5 & 125.1 & $\begin{array}{c}7.39(\mathrm{dd}, \mathrm{J}= \\
1.5,8.0)\end{array}$ & H 6 & $\begin{array}{l}\mathrm{C} 4 a,{ }^{e} \text { C } 4 b, C 6, \\
\text { C8a }\end{array}$ \\
\hline 6 & 126.4 & $\begin{array}{l}7.28(\mathrm{dd}, J= \\
8.0,8.0)\end{array}$ & H 5, H 7 & $\begin{array}{l}\text { C4b, C5, C7, C8, } \\
\text { C8a }\end{array}$ \\
\hline 7 & 125.9 & $\begin{array}{c}7.84(\mathrm{dd}, \mathrm{J}= \\
1.5,8.0)\end{array}$ & H 6 & $\begin{array}{l}\text { C4b, C5, C6, C8, } \\
\text { C8a, }{ }^{\mathrm{e}} \mathrm{C} 11\end{array}$ \\
\hline 8 & 118.3 & & & \\
\hline $8 a$ & 144.9 & & & \\
\hline 9 & & & & \\
\hline $9 a$ & 157.2 & & & \\
\hline 10 & 192.7 & $10.13(\mathrm{~s})$ & & $\mathrm{Cl}, \mathrm{C} 4 \mathrm{a}, \mathrm{C} 9 \mathrm{a}$ \\
\hline 11 & 168.2 & & & \\
\hline $\begin{array}{l}12 \\
1-\mathrm{OH}\end{array}$ & 53.4 & $\begin{array}{l}4.06(\mathrm{~s}) \\
8.50(\mathrm{bs})^{f}\end{array}$ & & C11 \\
\hline $9-\mathrm{OH}$ & & $8.50(\mathrm{bs})^{f}$ & & \\
\hline
\end{tabular}

a Spectra were recorded in $\mathrm{CD}_{3} \mathrm{OD} .{ }^{\mathrm{b}}{ }^{13} \mathrm{C} \mathrm{NMR}$ at $75 \mathrm{MHz}$ referenced to $\mathrm{CD}_{3} \mathrm{OD}(\delta 49.3)$, and assignments are supported by a gHSQC NMR experiment. ${ }^{{ }^{1} \mathrm{H}} \mathrm{NMR}$ at 300 and $500 \mathrm{MHz}$, referenced to residual solvent $\mathrm{CHD}_{2} \mathrm{OD}(\delta 3.3) .{ }^{\mathrm{d}} \mathrm{gHMBC}$ NMR experiments were run using $\mathrm{J}=140$ and $160 \mathrm{~Hz}$ and $\mathrm{J} n \mathrm{nh}=2,4$, 8, 9, $10 \mathrm{~Hz}$. ${ }^{e}$ These HMBC correlations were weak. ${ }^{f}$ This signal may be interchanged, and only one exchangeable proton was observed.

cis double bond $[\delta 6.25(\mathrm{~d}, \mathrm{~J}=10.2 \mathrm{~Hz})$ and $7.01(\mathrm{~d}, \mathrm{~J}=$ $10.2 \mathrm{~Hz}$ )]. Linkage of the fragments to give the core structure (2) arose from interpretation of COSY, gHSQC, and various $\mathrm{gHMBC} N \mathrm{MR}$ experiments, including a CIGAR HMBC (Table 1). ${ }^{2}$ An HMBC correlation from $\mathrm{H} 7$ to $\mathrm{C} 11$ confirmed that the methyl ester moiety was attached to the 1,2,3-trisubstituted aromatic ring system. Connectivity in the vicinity of the cis-ol efin present was assembled from the $\mathrm{HMBC}$ correlations from $\mathrm{H} 2$ to $\mathrm{C} 1$, the ketone $\mathrm{C} 4, \mathrm{C} 9 \mathrm{a}$, and the formyl $\mathrm{C} 10$ as well as from $\mathrm{H} 3$ to $\mathrm{Cl}$ and $\mathrm{C} 4 \mathrm{a}$. The key HMBC correlations that allowed closure of the core structure (2) were from $\mathrm{H} 7$ to $\mathrm{C} 8 \mathrm{a}$, from $\mathrm{H} 5$ to $\mathrm{C} 4 \mathrm{a}$ and $\mathrm{C} 8 \mathrm{a}$, and from H10 to C9a. Some of the observed HMBC correlations were weak and required data reacquisition using different coupling constant optimizations.

The core structure (2) accounted for all but one of the degrees of unsaturation and all atoms in the molecular formula except $\mathrm{H}_{2} \mathrm{NO}_{2}$. On the basis of the UV data and carbon chemical shift cal culations the core structure (2) was configured as a carbazole system (see $\mathbf{1}$ ) and the remaining atoms $\left(\mathrm{H}_{2} \mathrm{O}_{2}\right)$ were assigned as two $-\mathrm{OH}$ groups attached at positions $\mathrm{Cl}$ and $\mathrm{N} 9$ to give coproverdine (1). ${ }^{3}$ The 
deshiel ded quaternary carbon ( $\delta 90.5)$ was consistent with the substitution at $\mathrm{Cl}$ of a hydroxyl group and a deshielding functionality such as a formyl. ${ }^{4}$

Although the carbazol e skeleton of coproverdine (1) had been explicitly defined by the NMR and UV data, a computer-assisted constitutional assignment of coproverdine (1) was made using the structure calculation program COCON. ${ }^{5}$ The initial 510 structures that were calculated were reduced to eight that fitted the experimental data. Of these eight structures, that proposed for coproverdine (1) best fitted the experimental data in terms of the HMBC correlations and the closest ${ }^{1} \mathrm{H}$ and ${ }^{13} \mathrm{C}$ NMR shifts. The absolute stereochemistry of coproverdine (1) has not been assigned.

Due to the limited amount of coproverdine (1) isolated (5 mg), only small-scale $(<0.5 \mathrm{mg})$ chemical degradations were attempted in an effort to gain support for the proposed structure. Attempted methylation and acetylation reactions resulted only in complex mixtures or decomposition products. Reaction of $\mathbf{1}$ with acid resulted in interesting color changes (from yellow to green); however, the nature of this interconversion could not be clarified by mass spectrometry. Some limited support for the proposed structure came from the reduction of $\mathbf{1}$ with excess $\mathrm{NaBH}_{4}$ in dry $\mathrm{MeOH}$. A single compound was formed. On the basis of ESIMS analysis $\left(\mathrm{MH}^{+} 288\right)$ it is postulated that compound $\mathbf{4}$ was formed from the initial reduction product $\mathbf{3}$ by the loss of water (Scheme 1).

Biological evaluation of coproverdine (1) against a variety of murine and human tumor cell lines, which included P388, A549, HT29, MEL28, and DU145, established a cytotoxicity profile with I $C_{50}$ values of $1.6,0.3,0.3,0.3$, and $0.3 \mu \mathrm{M}$, respectively. The closest related compounds are carbazomycins $\mathrm{G}(5)$ and $\mathrm{H}(\mathbf{6})$, which were isolated from the culture broth of Streptoverticillium ehi mense in $1988 .{ }^{6}$ Carbazomycin G (5) was found to have some antimicrobial properties, and the total synthesis of both (5) and (6) was reported in 1997.6,7 Of interest is the plant alkaloid el lipticine (7), well-known for its cytostatic activity. ${ }^{8,9}$ Carba analogues of $\mathbf{7}$ have been synthesized, resulting in an analogue (8), which has structural similarities with coproverdine (1). ${ }^{10}$

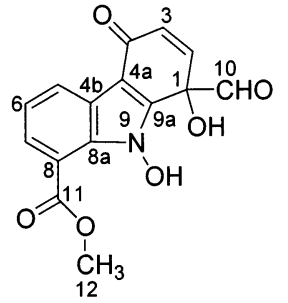

(1)<smiles>[R]c1ccc2[nH]c3c(c2c1)C(=O)C(OC)=C(C)C3(C)O</smiles>

(5) $\mathrm{R}=\mathrm{H}$

(6) $\mathrm{R}=\mathrm{OCH}_{3}$<smiles>Cc1c2cnccc2c(C)c2c1[nH]c1ccccc12</smiles>

(7)

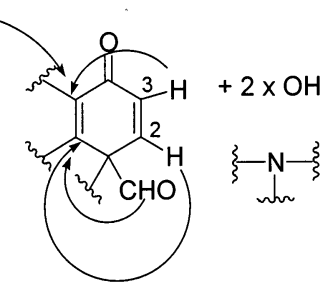

(2)

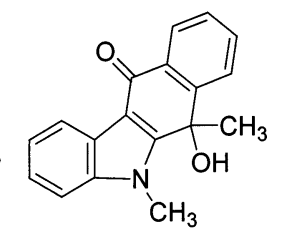

(8)
In the search for anticancer compounds the isolation of coproverdine (1) is a satisfactory outcome. A novel, bioactive structural type has been identified that is of low molecular weight, is a basic compound, has calculated log
Scheme 1. The Reduction of Coproverdine (1)

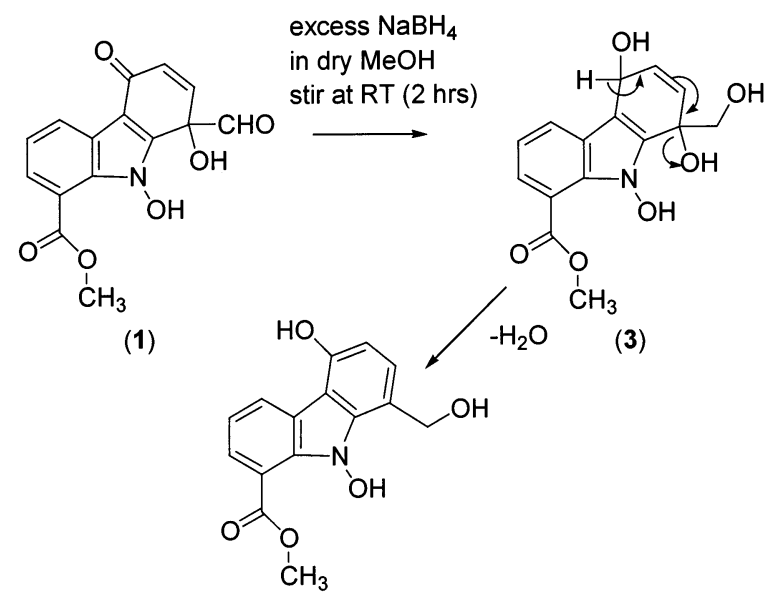

(4)

$P$ values of $-0.17,0.12$, or $-2.14,11,12$ and meets Lipinski's rules of five ${ }^{13}$ ( $<$ five $\mathrm{H}$-bond donors, molecular weight < 500 , the $\log P$ is $<5$, sum of N's and O's $<10$ and should have good absorption or permeation properties). An independent total synthesis of coproverdine (1) and analogues for SAR studies is underway. ${ }^{14}$

\section{Experimental Section}

General Experimental Procedures. All solvents were redistilled or of HPLC grade. BakerBond Octadecyl C18 (40 $\mu \mathrm{m})$ reversed-phase packing was used for vacuum liquid chromatography and Sephadex LH-20 for gel permeation chromatography. NMR spectra were recorded variously on Varian UNITY, XL $300 \mathrm{MHz}$, or INOVA $500 \mathrm{MHz}$ spectrometers. Electrospray mass spectra (ESIMS) were recorded in both the positive and negative modes on a Micromass LCT mass spectrometer, and electron impact mass spectrometry (EIMS) was carried out on a Kratos MS 80 RFA mass spectrometer. FABMS and HRFABMS were also recorded on the Kratos MS 80 RFA mass spectrometer using glycerol and m-nitrobenzyl alcohol (NOBA) as the matrix. LC/ESIMS was carried out on an Agilent technologies 1100 HPLC-MSD system using a Zorbax C8 column $(2.1 \mathrm{~mm} \times 15 \mathrm{~cm})$ at $40{ }^{\circ} \mathrm{C}$. The mass spectrometer was run using API-ES (+ve). The UV spectrum was obtained on a Hewlett-Packard 8452A diode array spectrophotometer, while the IR spectra were recorded on a Shimadzu FTIR-8201PC spectrophotometer. The optical rotation was recorded on a Perkin-Elmer 341 polarimeter (c $\mathrm{g} / 100 \mathrm{~mL}$ ) set to the $\mathrm{Na}$ wavelength $(589 \mathrm{~nm})$. Analytical HPLC was carried out on a Shimadzu VP system on a Phenomenex Prodigy $5 \mu$ ODS column (100 $\AA ; 250 \times 4.6 \mathrm{~mm}$ ) using a flow rate of $1 \mathrm{~mL} / \mathrm{min}$. Semi preparative reversed-phase HPLC was carried out on a Shimadzu LC-4A HPLC. The final purification conditions were carried out on a Phenomenex Prodigy $5 \mu$ ODS column (100 $\AA ; 250 \times 10 \mathrm{~mm}$ ) using a flow rate of $4 \mathrm{~mL} / \mathrm{min}$.

Collection, Extraction, and Isolation. A specimen of a rare, unidentified ascidian was collected from Irishman's Garden at the Three Kings, New Zealand. Collection was by scuba at a depth of 20-25 m from a rock wall in an exposed but shaded area of Irishman's Garden in March 1997. The specimen was described as epizoic on an Anchorina sp. sponge.

Collector's Description of the Organism. A colonial dark green/dark brown ascidian with round $1 \mathrm{~cm}$ high zooids with a common stol on was observed.

A voucher specimen is stored in the museum at NIWA, Wellington, N ew Zeal and (NI WA code M NP670). The specimen had been poorly preserved, and even after examination by Dr. Patricia Kott (Mather) (Queensland Museum, Australia) an opinion could be given only that is was possibly a polycitorid. The crude extract of this specimen displ ayed cytotoxic activity against fast growing P388 (murine leukaemia) cells (IC $\mathrm{C}_{50}=$ 
$0.95 \mu \mathrm{g} / \mathrm{mL}$ ) and also showed cytotoxicity against slow growing BSC-1 (African green monkey kidney) cells $(3+, 8)$. The frozen specimen (34 g) was exhaustively extracted with $\mathrm{MeOH} / \mathrm{DCM}$ $(3: 1 ; 700 \mathrm{~mL})$ and filtered through a pad of Celite, and the extract $(1.4 \mathrm{~g})$ was subjected to C18 vacuum liquid chromatography, followed by gel permeation chromatography on Sephadex $\mathrm{LH}-20$ eluting with $\mathrm{MeOH}$. The final purification was achieved using reversed-phase HPLC $\left(\mathrm{CH}_{3} \mathrm{CN} / \mathrm{H}_{2} \mathrm{O}\right.$ gradient (30\% to $75 \%$ ) over $30 \mathrm{~min}$ ) with UV detection at $254 \mathrm{~nm}$ to yield the major metabolite coproverdine (1) [5 mg, 0.01\% (based on mass of crude extract)].

Coproverdine (1) [8-formyl-8,9-dihydroxy-5-0xo-8,9dihydro-5H-carbazole-1-carboxylic acid methyl ester] yellow oil; $[\alpha]^{20}{ }_{D}-8^{\circ}$ (c 0.36 , EtOH); IR $\left(\mathrm{CHCl}_{3}\right) v_{\max } 3690$ (sharp), 3500 (br), 1665, 1603, 1556, $1290 \mathrm{~cm}^{-1}$; UV (EtOH) $\lambda_{\max }(\epsilon) 208$ (20 000), 270 (6700), 302 (4800), 382 (16000) nm; ${ }^{1} \mathrm{H}$ NMR data $\left(\mathrm{CD}_{3} \mathrm{OD}, 300 \mathrm{MHz}\right)$, see Table $1 ;{ }^{13} \mathrm{C}$ NMR data $\left(\mathrm{CD}_{3} \mathrm{OD}, 75 \mathrm{MHz}\right)$, see Table 1; ESIMS (-ve) (30 V) m/z 300 $[\mathrm{MH}]^{-}, 272\left[(\mathrm{MH})-\mathrm{CO}^{-} ; \mathrm{ESIMS}(+\mathrm{ve})(20 \mathrm{~V}) \mathrm{m} / \mathrm{z} 942\left[\mathrm{M}_{3} \mathrm{~K}\right]^{+}\right.$, $926\left[\mathrm{M}_{3} \mathrm{Na}\right]^{+}, 641\left[\mathrm{M}_{2} \mathrm{~K}\right]^{+}, 625\left[\mathrm{M}_{2} \mathrm{Na}\right]^{+}, 472\left[\mathrm{M}_{3} \mathrm{HK}\right]^{2+}, 340$ $\left[\mathrm{MK}^{+}, 324 \mathrm{MMN}^{+}, 302[\mathrm{MH}]^{+} ; \mathrm{El}(70 \mathrm{eV}) \mathrm{m} / \mathrm{z} 301\left(\mathrm{M}^{+}, 35\right)\right.$, 285 (75), 273 (24), 253 (48), 225 (100), 213 (28), 197 (26), 169 (28), 146 (20); FABMS (glycerol matrix, positive ion) m/z 302 $[\mathrm{MH}]^{+}, 277,185 ; \mathrm{LC} / \mathrm{MS} \mathrm{m} / \mathrm{z} 625\left[\mathrm{M}_{2} \mathrm{Na}\right]^{+}, 324[\mathrm{MNa}]^{+}, 302$ $[\mathrm{MH}]^{+}$; HREIMS m/z $301.05910\left([\mathrm{M}]^{+}\right.$, calculated for $\mathrm{C}_{15} \mathrm{H}_{11^{-}}$ $\left.\mathrm{NO}_{6}, 301.05864\right) ; \mathrm{HRFABMS} \mathrm{m} / \mathrm{z} 302.0673\left([\mathrm{MH}]^{+}\right.$, calculated for $\mathrm{C}_{15} \mathrm{H}_{12} \mathrm{NO}_{6}, 302.0665$ ).

Reduction of Coproverdine (1). Coproverdine (0.2 mg) together with $\mathrm{NaBH}_{4}(3.5 \mathrm{mg})$ and dry $\mathrm{MeOH}(3 \mathrm{~mL})$ were stirred at room temperature for $2 \mathrm{~h}$. The reaction mixture was concentrated under reduced pressure, redissolved in $\mathrm{MeOH}$ $(2 \mathrm{~mL})$, and analyzed by RPHPLC and mass spectrometry. The HPLC analysis indicated the presence of two compounds, which were more polar than coproverdine (1) but with the same UV profile. These compounds were suspected to be $\mathbf{4}$ as well as $\mathbf{3}$, but in the electrospray mass spectrum of the mixture the only product detected was that with a mass corresponding to 4 (low-resolution ESIMS (+ve) (30 V) m/z $288.21\left[^{[M H}\right]^{+}$, suggesting a possible molecular formula of $\mathrm{C}_{15} \mathrm{H}_{13} \mathrm{NO}_{5}$, calculated 287.2675).

Acknowledgment. We thank PharmaMar SA for providing financial support in the form of a Postdoctoral Research Fellowship (S.U.), as well as for further biological evaluation of coproverdine; Ms. G. Ellis (University of Canterbury) for biological assays; Mr. B. M. Clark (University of Canterbury) for mass spectral analyses; Dr. L. K. Pannell (NIDDK/NIH) for LC/MS; Mr. A. Duckworth (NIWA, New Zealand) for the collection of the specimen; and Dr. P. Kott (Mather) (Queensland Museum, Australia) for examining the voucher specimen.

Supporting Information Available: ${ }^{1} \mathrm{H} N M R$ in $\mathrm{CD}_{3} \mathrm{OD}$ as well as low-resolution ESI, EI, and FAB mass spectrometry data for coproverdine. This material is available free of charge via the Internet at http://pubs.acs.org.

\section{References and Notes}

(1) (a) Scott, A. I. Interpretation of the Ultraviolet Spectra of Natural Products; Pergamon Press: Oxford, 1964; Vol. 7, pp 297-298. (b) Fattorusso, E.; Forenza, S.; Minale, L.; Sodano, G. Gazz. Chim. Ital. 1971, 101, 104. (c) Kobayashi, A.; Kajiyama, S-i.; I nawaka, K. Kanzaki, H.; Kawazu, K. Z. Naturforsch. C Biosci. 1994, 49, 464.

(2) Hadden, C. E.; Martin, G. E.; Krishnamurthy, V. V. Magn. Reson. Chem. 2000, 38, 143.

(3) ${ }^{1 \mathrm{H}}$ and ${ }^{13} \mathrm{C}$ NMR estimation functions in Advanced Chemical Development Inc (ACD), 1994-2000.

(4) Patil, A. D.; Freyer, A. J .; Killmer, L.; Offen, P.; Carte, B.; J urewicz, A. J .; J ohnson, R. K. Tetrahedron 1997, 53, 5047.

(5) (a) J unker, J .; Maier, W.; Lindel, T.; Koeck, M. Org. Lett. 1999, 1, 737. (b) Koeck, M.; J unker, J .; Maier, W.; Will, M.; Lindel, T. Eur. J Org. Chem. 1999, 579. (c) Lindel, T.; J unker, J .; Koeck, M. Eur. J Org. Chem. 1999, 573. (d) Lindel, T.; J unker, J .; Koeck, M. J . Mol Model. 1997, 3, 364.

(6) Kaneda, M.; Naid, T.; Kitahara, T.; Nakamura, S.; Hirata, T.; Suga, T. J . Antibiot. 1988, 41, 603.

(7) Knölker, H.-J .; Fröhner, W. Tetrahedron Lett. 1997, 38, 4051

(8) Dalton, L. K.; Demerac, S.; Elmes, B. C.; Loder, J. W.; Swan, J . M. Teitei, T. Aust. J. Chem. 1967, 20, 2715.

(9) Svoboda, G. H.; Poore, G. A.; Montfort, J . J . Pharm. Sci. 1968, 57, 1720.

(10) Boogaard, A. T.; Pandit, U. K.; Koomen, G.-J . Tetrahedron. 1994, 50, 4811.

(11) (a) Estimation of logarithm of partition coefficient [n-octanol/water] log P by Crippen's fragmentation: J . Chem. Inf. Comput. Sci. 1987 27, 21. (b) Estimation of Iogarithm of partition coefficient [n-octanol/ water] log P by Viswandhan's fragmentation: J . Chem. Inf. Comput. Sci. 1989, 29, 163. (c) Estimation of logarithm of partition coefficient [n-octanol/water] log P by Broto's method: Euro. ] . Med. Chem.-Chim. Theor. 1984, 19, 71.

(12) Navia, M. A.; Chaturvedi, P. R. Drug Discovery Today Research Focus (Review) and references therein. 1996, 1, 179.

(13) Lipinski, C. 4th International Conference on Drug Absorption Edinburgh Scotland J une 13-15, 1997; pp 1-33.

(14) Morris, J. University of Canterbury, Christchurch, New Zealand (Personal communication).

NP010594Z 